\title{
RABAB PASISIA SELATAN DI MINANGKABAU DI AMBANG KEPUNAHANNYA
}

\author{
Silvia Rosa \\ Fakultas Ilmu Budaya Universitas Andalas \\ Pos-el: sylvie_rosha@ymail.com
}

\begin{abstract}
Abstrak
Barabab adalah suatu bentuk pertunjukan seni tradisi yang menyampaikan cerita kaba oleh seorang atau dua orang penampil dengan diiringi oleh permainan alat musik rabab (semacam alat musik gesek yang mirip biola). Pertunjukan Barabab berlangsung semalam suntuk. Biasanya pertunjukkan Barabab dihadirkan sebagai salah satu bentuk bungo alek (hiasan keramaian) dalam sebuah acara, baik perkawinan, perayaan atau peresmian peristiwaperistiwa penting dalam masyarakat adat di Minangkabau. Permasalahannya kini adalah realitas pewarisan seni pertunjukkan Barabab, Pewarisan aktif keterampilan mempertunjukkan seni tradisi Barabab tidak berlangsung baik dan berkesinambungan dari si pewaris aktif kepada generasi berikutnya.Penampil Barabab adalah pria-pria tua yang sudah berumur di atas 55 tahun dan atau lebih. Lalu bagaimana bila pewarisan tidak berlangsung lurus secara berkesinambungan dari generasi tua kepada generasi muda berikutnya. Tentu saja seni tradisi Barabab akan tinggal kenangan dan nama saja, berganti dengan corak musik Barat yang cenderung lebih diminati oleh generasi muda kini, misalnya organ tunggal dan sejenisnya. Kerisauan akan kepunahan seni tradisi Barabab ini sudah patut direncanakan tindakan penyelamatannya. Salah satu upayanya adalah dengan mencanangkan secara aktif untuk belajar budaya, khususnya belajar seni tradisi pertunjukan Barabab yang telah menjadi ikon seni pertunjukan penting di Pesisir Selatan.Upaya ini penting dilakukan secara terorganisir antara pemerhati budaya (perguruan tinggi) dengan Pemerintah Daerah Pesisir Selatan. Kebijakan-kebijakan pemerintah untuk membangun ruang atau tempat untuk belajar budaya, terutama seni Barabab, tindakan urgen untuk dirintis dan dikembangkan ke depan, dan sejak kini.
\end{abstract}

Kata kunci: barabab, kepunahan, pewarisan, dan revitalisasi

\section{THE BEGINNING OF THE EXTICTION OF RABAB PASISIA SELATAN TRADITION IN MINANGKABAU}

\begin{abstract}
Barabab is a form of traditional art performances that convey kaba story by one or two performers that are accompanied by rabab musical instrument (a kind of stringed instrument similar to a violin). The Barabab show lasted all night long. Usually Barabab shows are presented as a form of bungo alek (ornament of the crowd) in an event, whether marriage ceremony, celebration or inauguration of important events in indigenous peoples in Minangkabau. In the reality there is problem that Barabab active inheritance of Barabab's performing arts skills does not go well and sustain from the active performers to other generation. Barabab performers are old men over the age of 55. If the inheritance is not sustainable from older generation to other generation, the Barabab tradition will be extinct. One of the efforts to actively promote the learning of culture, especially learning the art of
\end{abstract}


tradition of Barabab show which has become an icon of important performing arts in South Coastal of Minangkabau. The effort is important to be done in an organized manner between cultural observers (universities) and the South Coastal Government. There is a crusial needs of government decision and policies to build space or place to learn culture, especially Barabab art.

Keywords: Barabab, extinction, inheritance, and revitalization

\section{PENDAHULUAN}

Kabupaten Pesisir Selatan merupakan daerah potensial pengembangan pariwisata Sumatera Barat. Kawasan yang terletak di sepanjang pesisir barat pulau Sumatera ini, menyimpan kekayaan alam dan budaya yang khas. Pengembangan sektor pariwisata Pesisir Selatan di masa depan hendaknya tidak hanya mengedepankan faktor alam yang mempesona saja, faktor budaya kawasan pesisir yang beragam dan menarik hendaknya juga dapat menjadi pertimbangan dalam mengemas paket-paket pariwisata Pesisir Selatan di masa datang.

Seni pertunjukan Barabab adalah salah satu aset budaya Pesisir Selatan yang tak ternilai harganya. Seni tradisi ini sangat populer di Minangkabau, akan tetapi ancaman kepunahan berada di ambang mata. Hal itu disebabkan oleh karena proses pewarisan keterampilan bermain rabab dari si pewaris aktif kepada generasi pewarisnya tidak terpelihara dan tidak terkondisi dengan baik, bahkan nyaris tidak ada. Fakta ini secara lambat laun akan mematikan seni tradisi Barabab dimasa depan. Secara otomatis, akan menghilangkan kesenian Barabab di tanah Minangkabau. Oleh karena itu, tindakan preventif penting dilakukan. Revitalisasi terhadap seni pertunjukan Barabab adalah salah satu upaya untuk menghambat kepunahan seni tradisi Barabab di Minangkabau.

Selain itu, belum pernah dilakukan kajian khusus yang berkatan dengan relasi antara gesekan bunyi alat musik rabab dengan aspek sastra (cerita) yang disampaikan dalam setiap pertunjukan rabab. Belum dapat diidenifikasi, sejauh ini, hubungan antara tempo gesekan bunyi alat musik rabab dengan mood dan suasana penceritaan, serta bagaimana hubungannya secara semiotik, khususnya terkait dengan makna teks cerita. Sesungguhnya, perhatian terhadap aspek-aspek ini amat penting diketahui mengingat kemampuan kebertahanan penonton dalam menikmatai permainan raba yang hampir selalu berlangsung semalam suntuk.Upaya pembongkaran makna dan relasi gesekan alat musik rabab dengan cerita yang disampiakn ini ditengarai dapat menjadi faktor penentu dalam tindakan pewarisan rabab secara komprehensif di daerah Pasisia

Identifikasi dan memetakan pewaris aktif seni tradisi Barabab yang masih ada penting dilakukan. Tindakan ini harus diikuti dengan suatu rancangan metode pewarisan yang tepat dan benar dari seorang pewaris aktif kepada generasi pewarisnya. Perencanaan dan penyediaan suatu sarana dan prasarana untuk melakukan tindakan pewarisan itu juga merupakan sesuatu yang tidak kalah pentingnya disamping tindakan pewarisan itu sendiri. "Rumah Rabab" adalah sebuah model yang dirancang untuk sarana dan prasarana pewarisan keterampilan dan kemahiran bermain rabab dari si pewaris aktif kepada generasi pewarisnya. Pada tahap inilah penelitian ini menjadi penting dan mendesak untuk dilakukan oleh perguruan tinggi (peneliti budaya) yang harus bekerjasama dan disuport oleh pemerintah daerah Kabupaten Pesisir Selatan itu sendiri. 
Penelitian ini penting dilakukan terutama ketika makin langkanya pewaris aktif seni tradisi Barabab di kalangan masyarakat Minnagkabau, khususnya di kabupaten Pesisir Selatan. Ketiadaan proses pewarisan keterampilan atau kemahiran melaksanakan tradisi Barabab ini, secara lambat laun akan menghilangkan, bahkan memusnahkan dan atau mematikan seni tradisi Bararab ini di suatu masa kelak. Apalagi hantaman budaya populer kian hari kian makin keras menghadang, misalnya seamakin dominannya masyarakat memberi apresiasi lebih kepada seni petunjukkan orgen tunggal, terutama pada malam-malam resepsi perhelatan kawin di Minangkabau.

Penelitian ini penting dilakukan dalam upaya tetap menjaga dan melestarikan keberadaan seni pertunjuan Barabab di Minangkabau, khususnya di kabupaten Pesisir Selatan. Permasalahan penelitian ini berkaitan dengan tiga aspek, yakni (1) bagaimana kondisi terkini seni tradisi Barabab di tengah kerasnya provokasi pengaruh budaya global di tanah Minangkabau ini; (2) dimana saja lokasi pewaris aktif seni tradisi barabab itu saat kini; (3) bagaimana upaya untuk melakukan pewarisan seni tradisi Barabab kepada generasi muda.

Revitalisasi seni tradisi Barabab dan perencanaan metode pewarisannya yang berskala Nagari harus dilakukan secepatnya di Kabupaten Pesisir Selatan. Untuk kepentingan itu, maka direncanakan tahapan-tahapan penelitian sebagai berikut:

1. melakukan identifikasi kondisi seni tradsisi Barabab di berbagai pelosok nagari di kabupaten Pessisir Selatan

2. memetakan daerah-daerah yang masih memiliki pewaris aktif seni tradisi Barabab di kabupaten Pesisir Selatan

3. merencanakan metode pewarisan keterampilan seni tradisi Barabab dari pewaris aktif kepada generasi pewarisnya
Penelitian ini penting dilakukan terutama ketika makin langkanya pewaris aktif seni tradisi Barabab di kalangan masyarakat Minnagkabau, khususnya di kabupaten Pesisir Selatan. Ketiadaan proses pewarisan keterampilan atau kemahiran melaksanakan tradisi Barabab ini, secara lambat laun akan menghilangkan, bahkan memusnahkan dan atau mematikan seni tradisi Bararab ini di suatu masa kelak. Apalagi hantaman budaya populer kian hari kian makin keras menghadang, misalnya seamakin dominannya masyarakat memberi apresiasi lebih kepada seni petunjukkan orgen tunggal, terutama pada malam-malam resepsi perhelatan kawin di Minangkabau.

Penelitian ini penting dilakukan dalam upaya tetap menjaga dan melestarikan keberadaan seni pertunjuan Barabab di Minangkabau, khususnya di kabupaten Pesisir Selatan.Tindakan ini penting dalam hal (1) sebagai salah satu upaya untuk melestarikan seni tradisi Barabab di tengah kerasnya provokasi pengaruh budaya global di tanah Minangkabau ini.(2) memahami daya tarik atau pesona seni tradisi rabab bagi masyakarat pendukungnya, khususnya masyarakat pasisia, dan umumnya masyakat Minangkabau (3) memetakan kondisi seni tradisi Barabab itu sendiri saat ini. (4) melakukan upaya revitalisasi seni tradisi Barabab itu di ranah Pesisir Selatan.

\section{METODE}

Penelitian ini menggunakan metode deskriptif kualitatif. Metode seperti ini dianggap akan dapat memberikan sejumlah informasi kualitatif yang bermakna. Untuk tujuan seperti ini digunakan strategi survai, yang diharapkan dapat mengumpulkan beberapa variabl yang terkait dengan sejumlah sejumlah individu dengan alat pengukur wawancara.Wawancara dilakukan kepada sejumlah penampil seni tradisi Barabab sebagai pewaris aktif. Selain itu, tokoh-tokoh masyarakat setempat yang 
dianggap mampu memberikan informasi terkait dengan seni tradisi Barabab juga akan diwawancarai. Informasi mengenai cirri-ciri demografis masyarakat, lingkungan social, budaya, aktivitas, sikap dan pendapat masyarakat juga termasuk dalam informasi yang dibutuhkan.

Untuk mencapai tujuan tersebut dibutuhkan alat bantu wawancara berupa panduan pertanyaan yang bersifat terbuka dan bebas. Informan terdiri dari pewaris aktif (tukang rabab), pemuka masyarakat dan tokoh terkait yang memahami seni tradisi Barabab.Teknik analisis data berlangsung secara induktif. Pemakaian teknik ini dimaksudkan untuk lebih mendapatkan kenyataan ganda di dalam data, dan juga untuk lebih memungkinkan menguraikan latar secara penuh (Moleong, 2000: 5). Analisis data berawal sejak data mulai dikumpulkan di lapangan sampai keseluruhan proses penelitian berakhir. Data secara terus menerus dianalis dan mengalami pemekaran analisis dari waktu ke waktu, sehingga akan memperkaya penafsiran terhadap data yang telah dikumpulkan. Setting budaya tempat data seni tradisi Barabab dikumpulkan adalah faktor penting yang membantu mengembangkan penafsiran itu kelak.Oleh karena itu data yang berasal dari hasil catatan lapangan sangat dibutuhkan.

Data yang telah dianalisis seterusnya ditafsirkan secara deskriptif analitik. Dengan cara demikian klasifikasi data sastra lisan yang semula telah ada akan dimungkinkan untuk terus bertambah. Dengan demikian akan selalu terjadi keterjalinan antara analisis data sastra lisan yang dikumpulkan dengan penafsirannya. Berdasarkan keterjalinan analisis dengan penafsiran data itu akan di maknai struktur batin (deep structure) sastra lisan yang dikumpulkan. Selanjutnya akan ditafsirkan dengan pendekatan stuktural dan semiotik.

\section{HASIL DAN PEMBAHASAN}

Lihat foto berikut yang memperlihatkan bentuk alat musik rabab Pasisia sekarang dan sebuah pola yang digunakan oleh pembuat alat musik rabab untuk mencetak pola tubuh rabab di Pasisia.

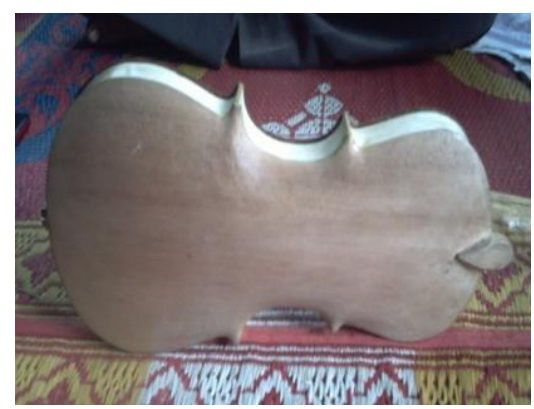

Foto: Bahagian punggung rabab (Dokumentasi: Silvia Rosa)

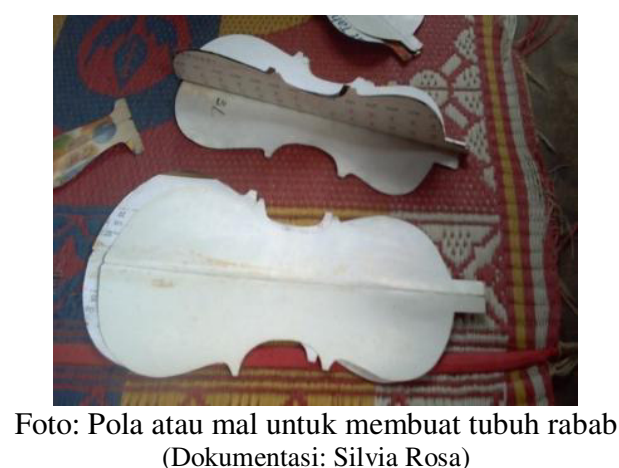

Rabab adalah sejenis alat musik gesek, yaitu bunyi dihasilkan dari proses menggesek sebuah tongkat (panggosok) kepada senar atau tali yang dipasang di bahagian atas tubuh rabab. Pada zaman dahulu, tali rabab itu belum terbuat dari senar gitar sebagaimana dikenal sekarang. Tali rabab itu dibuat dengan memanfaatkan benang nilon dan sebuah tali yang diambil dari tali rem sepeda yang berpilin-pilin itu. Tali rabab itu, awalnya hanya tiga buah saja. Dua buah yang terbuat dari benang nilon dipakai sebagai benang atau tali yang berfungsi untuk manggitiak (yang menghasilkan bunyi biasa), sedangkan yang satu lembar lagi yang terbuat dari tali rem sepeda berpilin itu berfungsi untuk menghasilkan bunyi dengung pada alat musik rabab. Sementara tali yang dipakai untuk alat panggosok terbuat beberapa 
lembar atau helai ekor kuda. Beberapa helai ekor kuda yang halus diluruskan dan dikumpulkan untuk menjadi tali penggosok alat musik rabab. Akan tetapi, sesuai dengan perkembangan dan kemajuan zaman, yaitu dikenalnya tali senar yang dipakai pada alat musik gitar, maka benang nilon yang dipakai untuk tali yang dipasang pada tubuh biola diganti dengan senar gitar, sedangkan benang ekor kuda yang dipakai sebagai tali pada alat panggosok diganti dengan benang nilon yang paling halus. Seiring dengan tuntutan selera dan perkembangan variasi irama, tali rabab pun kini menjadi empat buah. Satu buah tali yang diletakkan pada posisi tali ke-4 dipakai sebagai tali penghasil bunyi dengung. Bunyi dengung inilah yang menghasilkan kesan syahdu dan pilu pada alat musik rebab ini. Lihat posisi tali yang bertugas menghasilkan bunyi dengung pada alat musik rabab berikut ini:

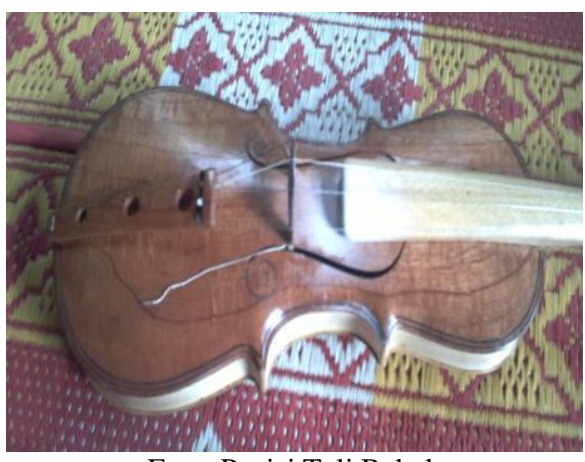

Foto: Posisi Tali Rabab

Yang Menghasilkan Bunyi Dengung (Dokumentasi: Silvia Rosa)

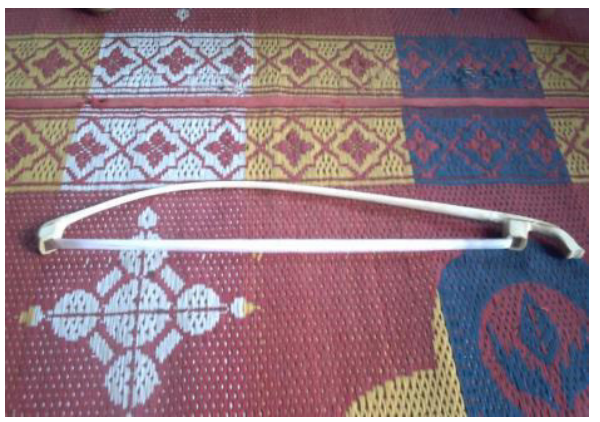

Foto: Panggosok

(alat yang digesekkan ke tali biola) (Dokumentasi: Silvia Rosa)
Barabab sejak itu dikenal sebagai seni tradisinya kaum nelayan di aerah pesisiran pantai Barat Sumatera, khususnya di Pesisir Selatan dan di kabupaten Padang Pariaman. Perbedaan kedua jenis seni tradisi rabab di kedua daerah ini terletak pada alat bentuk alat musik dan nuansa irama yang dihasilkan rebab pada kedua daerah itu. Rabab di Pariaman lebih bernuansa klasik, nadanya terbatas, sedangkan rabab di tanah Pasisia lebih variatif dan dapat menghasilkan nuansa irama yang lebih beragam, bahkan dapat mengkombinasikan dengan alat-alat musik lainnya, seperti gendang, chaar, dan juga saluang. Hal inilah yang menyebabkan rabab Pasisia lebih banyak digemari dan banyak diminati pendengar, tidak terkecuali para perantau Minangkabau.

\section{Alat Musik yang Dipakai}

Alat musik rabab terbuat dari kayu. Biasanya kayu yang dipilih adalah kayu yang bagus, kuat dan sangat disukai jika kayu itu menpunyai motif atau ragi-ragi yang lebih jelas dan kentara. Motif atau ragi itu bila nanti kayunya dipotongdan akan menjadi hiasan pada tubuh dan punggung rabab. kayu yang sering dipakai untuk membuat tubuh rabab itu adalah kayu yang bernama surian, jati, jariang, lansano. Pemilihan bahan kayu yang baik dan bagus akan menghasilkan rabab yang berkualitas, dan berseni tinggi. Rabab yang bagus akan tampak dari jauh, apalagi bila suara yang dikeluarkan dari alat musik rabab itu juga bagus, maka akan semakin sempurna, estetislah, dan menarik minat penonton rabab untuk menyaksikan pertunjukan rabab. pemilihan keras dan lunaknya kayu juga berpengaruh pada alat musik rabab.

Apabila kayu yang dipilih untuk membuat bagian punggung tubuh rabab berasal dari kayu yang bertekstur keras, maka bagian badan muka rabab harus dibuat dari kayu yang bertekstur agak lunak dari kayu yang dipakai untuk 
membuat bagian punggung rabab. bila dipilih kayu yang sama-sama bertekstur keras untuk kedua sisi tubuh rabab, maka bunyi rabab yang dihasilkan lebih bersuara nyaring atau lantang. Suara yang nyaring atau lantang ini tidak bagus untuk rabab. Sebaliknya, bila kedua sisi tubuh rabab itu dibuat dari kayu yang sama-sama bertekstur lunak, maka alat musik rabab yang dihasilkan akan mengeluarkan bunyi yang tidak bagus juga. Oleh karena itu kayu yang dipilih untuk membuat kedua sisi badan tubuh rabab itu harus berbeda teksturnya antara bagian punggung dengan bagian tubuh depan. Salah satunya harus bertekstur keras dan yang lainnya bertekstur lunak. Bila pemilihan tekstur bahan kayu benar maka rabab itu akan menghasilkan bunyi yang nyaring dan juga ada yang berbunyi lembab atau yang dalam nada rabab disebut bunyi gauang (gaung).

Selain pemilihan tekstur bahan kayu yang perlu dipertimbangkan dalam proses pembuatan alat musik rabab, bentuk permukaan kayu yang dipakai untuk membuat tubuh bagian depan dan bagian punggung juga harus diperhatikan. Bila permukaan kayu yang dipakai untuk membuat tubuh bagian depan berbentuk agak cembung, maka bentuk permukaan kayu yang dibuat untuk bagian punggung harus datar dan lurus. Apabila tidak memperhatikan faktor tersebut, misal permukaan kayu kedua bagian sisi tubuh sama-sama cembung maka bunyi suara rabab yang dihasilkan akan tertahan-tahan, sebaliknya bila sama-sama datar dan lurus, maka bunyi suara rabab yang dihasilkan akan berputar-putar dalam rongga tubuh rabab itu saja.

Bunyi suara rabab yang ideal akan berhasil dengan baik jika proses pemilihan kayu pembuatan rabab, memperhatikan aspek keseimbangan pada pemilihan permukaan kayu yang dipakai untuk membuat bagian tubuh depan dan bagian punggung rabab. Bunyi suara rabab yang ideal akan terjadi dari tindakan ketelitian memilih bahan kayu dan bentuk permukaan kayu tersebut. Bunyi yang ideal adalah bunyi yang terbentuk dari proses gesekan tangan tukang rabab, lalu bunyi itu melantun ke bagian siriang, kemudian bunyi itu berputar di bagian bawah tubuh rabab, kemudian perputaran di bagian bawah itu diteruskan atau dipantulkan ke bagian hidung rabab. Lobang yang terdapat pada bagian hidung rabab tidak boleh terlalu besar. Kalau dibuat besar lobangnya akan menghasilkan bunyi yang cenderung double, besar, dan tidak bagus. Oleh karena itu lobangnya dibuat agak mengecil supaya bunyi yang dipantulkan lebih bisa tertahan.

Bagian depan tubuh rabab dan bagian punggung tubuh rabab dipersatukan oleh selembar kayu yang disebut dengan siriang. Siriang biasanya dibuat dari kayu si cerek, karena kayu jenis ini sangat lentur dan tidak mudah patah. Pemasangan siriang sebagai penghubung kedua belahan sisi tubuh rabab harus ditopang pula oleh sebuah kayu yang dijepitkan di bagian dalam rongga tubuh rabab. Bila tidak dilakukan dengan cara demikian, maka siriang itu tidak akan bisa terpasang. Ada cara lain yang juga ditemukan berdasrkan pengalaman informan yang kami wawancarai, yaitu mengikatkan kedua sisi tubuh rabab itu dengan bantuan selembar karet yang terbuat dari bahan benen. Lalu, setelah kedua bagian tubuh rabab itu terpasang dan terhubung dengan selembar siriang, maka dilakukan pengeleman. Proses pengeleman ini harus benar-benar rapat dan rapi agar supaya tidak ada celah yang bisa membuat udara keluar masuk dengan bebas dan percuma. Foto berikut memperjelas keterangan dan pemahaman tentang bagian yang disebut siriang yang menghubungkan bagian depan tubuh rabab dengan bagian punggungnya. 


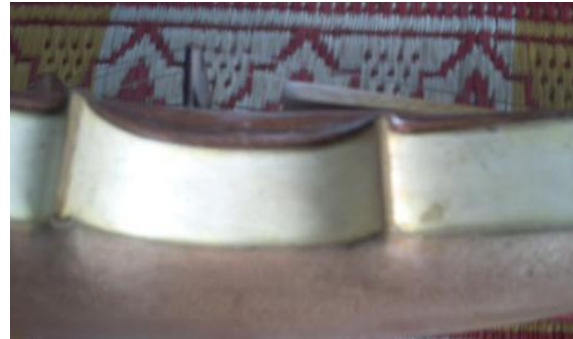

Foto: Bagian Siriang yang menghubungkan kedua sisi tubuh rabab

(Dokumentasi: Silvia Rosa)

Demikian juga dengan penempatan posisi bagian lidah rabab harus ditahan supaya tidak terlalu ketinggian. Bila terlalu tinggi posisi lidah rabab ini, maka akan menghasilkan bunyi gesekan rabab yang terbang melayang, tapi bila posisi lidahnya lebih merapat, maka akan menghasilkan bunyi gesekan yang taneh (mantap). Selain itu, juga penting sekali memperhatikan posisi bagian rabab yang disebut 'kudokudo' (kuda-kuda). Bagian kudo-kudo ini diberi tiang yang tepat dan pas ukurannya, jika tidak diberi tiang dalam posisi yang pas dan tepat, maka turut berpengaruh dalam menghasilkan bunyi gesekan rabab yang bagus.

Aspek lain yang juga tidak kalah pentingnya untuk diperhatikan ketepatan dan ketelitian adalah posisi perekatan bagian kudo-kudo, bagian lidah, bagian tupai-tupai, dan juga posisi dan letak bagian hidung alat musik rabab. Kesemua posisinya harus berimbang dan seimbang. Rabab diibaratkan sebagai tubuh manusia. Oleh karena itu bagian-bagian rabab dinamai sesuai dengan nama anggota tubuh manusia. Filosofi yang berlaku pada tubuh rabab sama dengan filosofi pada tubuh manusia karena tubuh rabab itu terdiri dari bagian-bagian yang disebut sebagai : kepala, telinga, lidah, hidung, leher, badan depan, badan bagian belakang (punggung), tupai-tupai, kudo-kudo, tiang arasy (tiang yang menghubungkan bagian tubuh depan dengan bagian tubuh belakang (punggung), siriang, pusek (pusar). Filosofi nan ampek juga tampak pada rabab, yakni tali rabab sekarang terdiri dari empat buah. Ini mencerminkan segala sesuatu yang empat pada manusia, yaitu sahabat nabi yang berempat, kato nan ampek, suku nan ampek dan lain sebagainya yang serba empat dalam filosofi orang Minangkabau. Pengibaratkan rabab dengan manusia ini, konon kabarnya yng membuat alat rabab pada suatu masa dapat dipakai sebagai alat perantara untuk mangganjua (menggunagunai) seseorang. Oleh karenanya, pada masa dulu, tak jarang persaingan sesama perabab turut menyertakan aspek magic dengan memanfaatkan tubuh rabab. Kabarnya dulu kala, tiba-tiba bisa saja tali rabab putus mendadak ketika pemain rabab sedang on air, atau bisa juga suara tukang rabab tiba-tiba tidak bisa keluar karena ada yang menahan suaranya dengan berbekal ilmu magic. Akan tetapi, saat ini persaingan tidak sehat itu sudah jarang ditemukan. Kalau masih ada kasus mirip yang ditemukan, itu hanya dilakukan oleh penonton atau orang yang baru mempunyai ilmu baru secara magic, lalu menembakkannya kepada pemain rabab.

Proses pembuatan alat musik rabab ini gampang-gampang susah. Bisa gampang kalau tahu caranya. Bagi informan yang kami wawancarai, ia bisa membuat rabab dalam tiga hari. Sebenarnya, dalam satu hari bisa diselesaikannya pembuatan alat musik rabab itu, namun itu masih kasar. Proses penghalusan dan perapiannya memerlukan waktu dua hari. Proses finishing buth waktu dua hari. Tahap finishing ini diperlukan untuk melakukan tindakan penghalusan sampai tiga kali. Pertama kali dengan menggunakan amplas bertekstur kasar, seterusnya yang bertekstur menengah, terakhir baru dihaluskan dengan amplas bertekstur yang lebih halus. Ketelitian, kebersihan proses pengerjaannya ini yang membuat rabab tampak bagus, licin, halus dan bernilai seni yang tinggi. Selain itu perekatan siriang harus benar-benar sama tinggi, bila tidak sama tinggi akan menghasilkan bunyi rabab yang baliang (fals). 
Informan yang kami wawancarai sudah membuat alat musik rabab sejak tahun 2011. Ia telah memproduksi alat musik rabab sekitar 100 buah. Alat musik rabab yang diproduksinya itu telah dibeli dan dikoleksi oleh berbagai kalangan. Taman Budaya Provinsi Sumatera Barat pernah membeli sebanyak 35 buah hasil produksi rababnya. Rupanya keterampilan yang dimiliki Yosarman tidak hanya bermain rabab, tetapi juga membuat alat musik rabab. Tidak mengherankan bila kehidupan dirinya dan keluarganya bertopang penuh dari seni tradisi barabab ini. Sebuah alat rabab yang diproduksinya bisa laku terjual dengan harga Rp 400.000 s/d 700.000 per buah. Belum lagi honor atau bayaran yang diterimanya setiap kali pentas dengan kelompoknya berkisar antara Rp 1 juta s/d 4,5 juta. Harga honor Rp 1 juta s/d 2,5 juta berlaku untuk pentas di berbagai tempat di dalam kabupaten Pesisir Selatan, sedangkan bila pentas di luar kabupaten Pesisir Selatan, honor pementasannya berkisar antara Rp 3 juta s/d 4,5 juta.

Awalnya, Yosarman tidak pandai membuat alat musik rabab, tetapi tersebab oleh karena kekecewaannya kepada kakak iparnya yang tidak bersedia memperbaiki rabab miliknya yang rusak, maka ia bertekad untuk mencoba belajar membuat rabab sendiri. Mulailah Yosar meminjam pola atau maal untuk membuat cetakan atau pola badan rabab kepada temannya di Balai Selasa. Setelah dapat maal, ia meminta tolong memotongkan kayu ke tukang perabot. Kayu itu dibelah dua, ditipiskan sampai lebih tipis dari triplek. Kemudian ia terbentur dengan teknik pemasangan siriang. Atas bantuan temannya, ia mendapat trik untuk memasang siriang yang terbuat dari kayu si cerek itu.

Alat musik lain selain rabab yang dipakai dalam seni pertunjakan barabab adalah gandang duo, gandang ciek, chaart, dan perkembangan terakhir dikombinasikan dengan saluang. Sebenarnya, bentuk awalnya hanya satu alat musik saja yang dipakai dalam pertunjukan, yaitu rabab. Namun, tuntutan variasi dan selera penonton dan kesenangan tukang rabab Pasisia bereksperimen, maka ditambah dengan pengkombinasian alat musik gandang duo, gandang ciek, dan chaar. Penambahan ketiga jenis alat musik terakhir ini menyebabkan bunyi pertunjukan seni barabab di tanah Pasisia menjadi lebih variatif dan digemari banyak penonton. Foto berikut memperlihatkan alat musik yang menjadi tambahan dalam pertunjukan seni barabab.
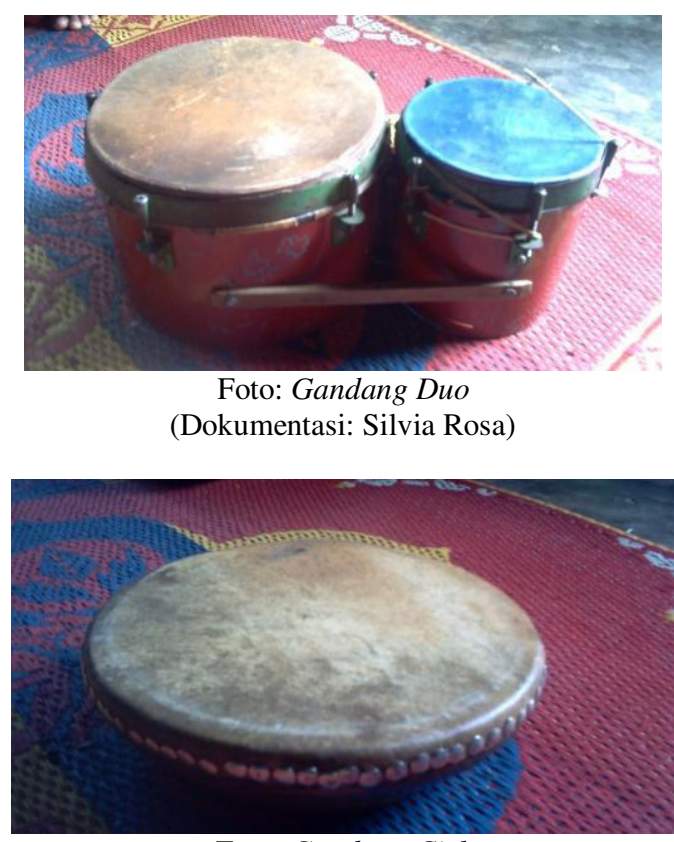

Foto: Gandang Ciek (Dokumentasi: Silvia Rosa)

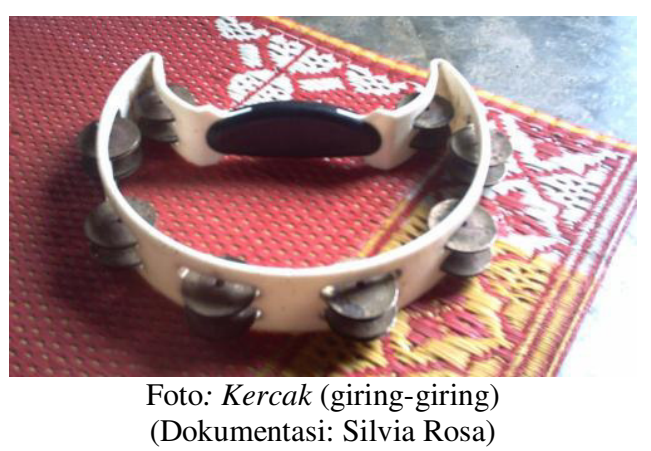




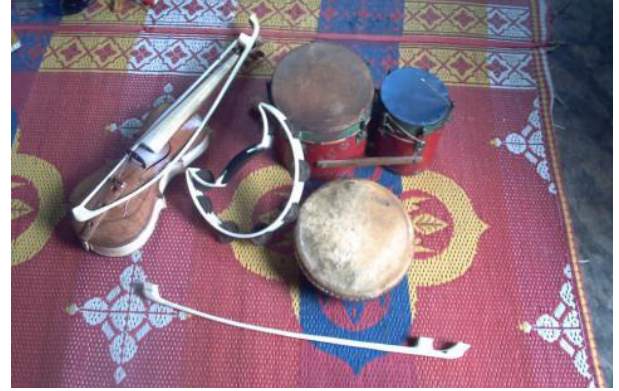

Foto: Seperangkat alat musik pengiring seni pertunjukan Barabab (Dokumentasi: Silvia Rosa)

\section{Struktur Pertunjukan Barabab}

Struktur isi pertunjukan Barabab terdiri atas 4 yaitu, (a) Si kambang; (b) Peruntungan; (c) Nyanyian bebas; (d) Carito; (e) Sulo Basi; dan (f) Pacaraian. Si Kambang merupakan bagian pertunjukan rabab yang menampilkan etika memulai sebuah pertunjukan. Pada bagian ini si penampil menyampaikan salam dan persembahan kepada penonton dan juga permintaan maaf atas kedatangan dan kehadiran mereka di dalam acara yang sedang ditampilkannya. Bagian si kambang ini dihantarkan dalam empat macam model lagu, yaitu lagu Si Kambang Data, Si Kambang Batang Kapeh, Si Kambang Aia Tajun, dan Si Kambang Lagan. Keempat jenis lagu ini rada susah untuk membedakannya karena hanya sedikit sekali perbedaannya. Si Kambang Data terasa sekali alunan gesekan rababnya tenang, suara perabab juga tenang dan datar, bahkan dengan notasi sangat rendah. Penonton yang mendengarkan akan terhanyut dengan alunan bunyi rabab yang sendu dan mendayu-dayu. Perubahan ke alunan gesekan rabab yang agak bervariasi menandakan lagu si Kambang Data berpindah ke lagu si Kambang Batang Kapeh. Bagian ini masih dipakai untuk menjelaskan maksud dan rencana pertunjukan mereka pada saat itu, serta menyampaikan ucapan terima kasih kepada tuan rumah yang telah dan sedang berbahagia di malam pesta pernikahan anggota keluarganya yang dimeriahkan dengan pertunjukan rabab pada malam itu.
Perkenalan dan sapa penonton juga masih disampaikan pada bagian ini. Setelah itu, alunan gesekan rabab dan suara tukang rabab mulai meninggi dan agak cepat, lagu pun berpindah ke Si Kambang Aia Tajun. Pada bagian ini mulai diperkenalkan tokoh cerita yang akan dikisahkan. Nada gesekan rabab sudah agak naik, demikian juga suara perabab maupun bunyi nada rabab, dan agak lebih banyak berliku-liku dan meraung-raung. Ini juga memberikan warna yang agak meriah. Bila lirik bercerita tentang kisah-kisah apakah tentang seseorang atau tentang suatu benda atau sesuatu peristiwa makan dipakai bagian ini untuk mengiringinya. $S i$ Kambang Aia Tajun terasa lebih menggigit-gigit nadanya dan memekikmekik syahdu. Sudah menyabut-nyebut nama tokoh atau menyeru-nyeru tokoh2. Salah satu lirik yang diucapkan tukang rabab pada bagian ini seperti kutipan berikut ini :

Balayialah nyo pelaaaaang oiii tuan eeeeiiii.... oooiii ka lauiiiiiik iiiii taaaaaan ooo tuan eeeeeiiiii.

Ooooo.... ampun lah baribuиии.....ooooo lah kaliiiii lah aaaampuuunnnn eeeeiiii....

Ooooo....ntaaah lah tabilaaang ooooo lah di nan bukaaaan eeeeeiiiiiii....

Oooooo...... tolooooong banaaaaaa oooo tuan eeeiiiiiiii... oooooooo sakali lah kiniiiiiiii..... aaaaaaaaaa......

Setelah larik terakhir disampaikan dengan mendayu-dayu, maka nada lagu pun langsung menghantarkan suasana ke bagian awal cerita yang telah disiapkan oleh tukang rabab dengan memakai lagu si Kambang Lagan. Ciri-ciri lagu si Kambang Lagan adalah nada alunan rabab menjadi makin tinggi dan terasa lebih ramai dan meriah. Salah satu lirik yang diucapkan oleh tukang rabab seperti terpapar dalam kutipan berikut: 


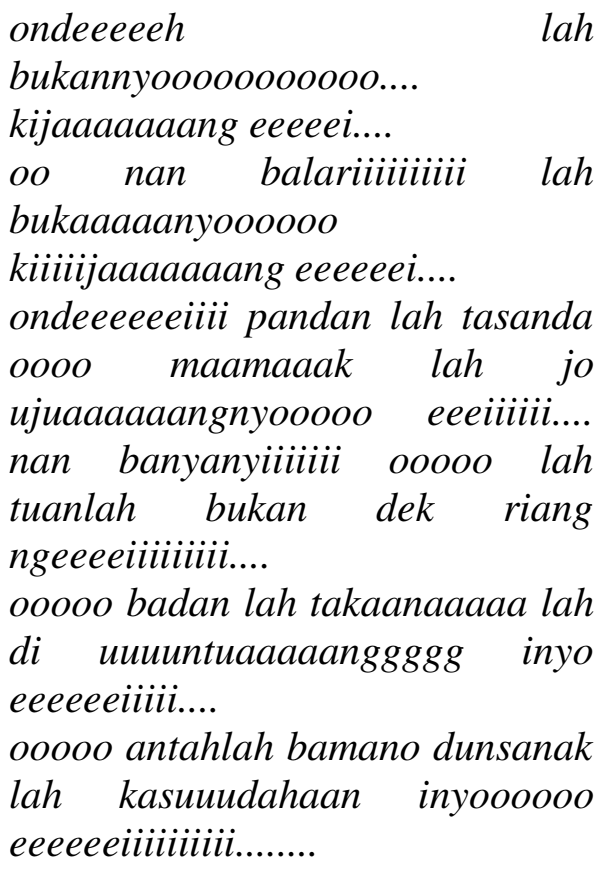

Sesudah larik yang dihantar dengan lagu si Kambang Lagan ini berakhir, maka dendang pun dimulai. Bagian dendang adalah porsi untuk menyampaikan kisah cerita yang ingin dituturkan si tukang rabab pada malam pertunjukan itu. Banyak tukang rabab yang tidak mampu menghantarkan suasana dan perasaan penonton menjadi damai, tenang, syahdu sebelum mendengarkan kisah cerita yang dituturkan. Hal itu tersebab karena banyak tukang rabab yang mengabaikan untuk mengoptimalkan penyampaian porsi bagian Si Kambang. Tukang rabab banyak yang hanya mengantar sedikit saja pada alunan lagu pembukaan, setelah itu langsung masuk ke bagian kisah cerita. Akan lebih baik bila perabab mampu menenangkan dulu jiwa, pikiran dan perasaan penonton dengan gesekan rabab yang memaksimalkan penyampaian bagian $\mathrm{Si}$ Kambang ini. Namun kelebihan keterampilan itu tidak semua perabab memilikinya. Perabab yang pemula sering tidak peduli dengan bagian ini. Intinya, belum tercapai persatuan jiwa si perabab dengan bunyi rabab dan suasana pertunjukan. Sesungguhnya bila perabab sudah berhasil khusuk bersatu dengan bunyi rababnya, maka penonton pun akan tersentuh perasaannya. Oleh karena bermain rabab itu adalah bermain perasaan, bermain batin yang paling dalam. Bila perlu, perabab hendaknya lebih dulu menangis dan tersudut dalam kesedihan, kepedihan, pilu yang mendalam ketika sedang menggesek rababnya. Bila hal ini yang dilakukan perabab ketika sedang dalam pertunjukannya, maka penonton akan terbawa menangis haru dan pedih atas tragedi yang dikisah oleh si tukang rabab itu. Keadaan demikian agaknya cocok dengan salah satu ungkapan lirik rabab yangberbunyi " jikok dikana-kana riwayat nan dulu, kini manjadi ratok tangih" " jika diingat-ingat riwayat yang dahulu, kini menjadi ratap tangis).

$$
\text { Usai bagian si Kambang }
$$
dipertunjukan, maka masuk ke bagian berikutnya yang disebut dengan Paruntuangan (peruntungan). Bagian ini berisi cerita, bisa bersumber dari kaba klasik dan bisa juga bahan nya dari kisahkisah yang lebih aktual. Untuk bagian ini biasanya mendapat respon yang lebih tinggi dari penonton kalanga tua, setidaknya sudah dewasa dan berumah tangga. Penonton dari golongan mudamudi terkadang kurang apresiatif terhadap bagian ini. Biasanya bagian paruntuangan berisi kisah tragedi kehidupan seorang tokoh. Akan tetapi, bagian ini bisa juga dialihkan ke kisah yang disukai oleh penonton muda-mudi, terutama bila khalayak penonton yang hadir di pertunjukan itu adalah mayoritas mudamudi. Oleh karenanya si tukang rabab harus cepat dan pandai-pandai membaca selera penonton yang hadir dalm pertunjukannnya. Bila kesesuaia kisah yang dituturkan bersambut dengan selera penonton mayoritas, maka penonton akan bertahan sampai larut malam.

Bagian paruntuangan dapat juga dihiasi dengan dendang perantauan, atau dendang kasih di rantau, atau dendang kasih di kampung yang diarahkan ke 
perantauan. Pilihan-pilihan dendang ini akan mampu membuat penonton bertahan lama dan senang mendengarkan dendang si tukang rebab. Misal, seorang anak pergi merantau, nestapa di kampung lalu pergi ke rantau, dan bahagia di rantau. Itu dibentuk melalui dendang yang sesuai dengan alur kisah hidup tokoh yang pergi merantau itu.

Tema-tema cerita dendang ini dibuat dan dipilih dan dikondisikan oleh si tukang rebab. Dendang adalah karangan si tukang rebab. Dendang tidak sama dengan carito yang disampaikan. Kisah-kisah tragedi kehidupan seorang bisa disampaikan dalam carito yang disampaikan dalam rabab. Itu disampaikan dalam bahagian cerita rabab, bukan bagian dendang. Cerita adalah bagian yang dikisahkan, sementara dendang adalah suasana lukisan yang menjadi latar penceritaan kisah yang akan dibawakan. Dendang adalah karangan, kalau kaba adalah cerita. Tanpa ada dendang pertunjukan rabab terasa seperti air yang mengalir saja, lurus dan lancar. Dendang seperti dikatakan tadi adalah latar suasana yang membentuk emosi dan mampu menggugah perasaan penonton. Dendang ada maknanya sendiri dan juga ada maksudnya sendiri.

Bagian paruntuangan ini kemudian diberi jeda sejenak, dan disela dengan menyuguhkan bagian nyanyia bebas. Bagian ini berfungsi untuk kembali membangkitkan dan menggembirakan selera dan perasaan penonton yang terlanjur hanyut dan larut dalam kesedihan. Pada bagian nyanyian bebas ini biasanya pemakaian alat musik gendang dimaksimalkan, terasa lebih meriah dan dapat menghidupkan suasana. Setelah dimeriahkan dengan bagian nyanyian bebas, kemudian kembali masuk ke bagian penyampaian cerita atau kisah yang dihentikan sesaat ketika nyanyian bebas dimainkan. Setelah lama menghantarkan cerita, perabab akan berbalasa-balasan menembak atau memantunkan penonton silih berganti. Bagian ini termasuk dalam bagian yang disebut sulo basi. Bila itu sudah berakhir, kembali lagi ke bagian cerita. Hingga menjelang subuh tiba. Bila sudah tiba saatnya menjelang subuh itu, maka selesai atau tidak selesai pertunjukan harus disudahi. Penyudahan pertunjukan itu disebut dengan bagian perceraian.

\section{Keberadaan Pewaris Aktif Seni Pertunjukan Barabab}

Saat ini masih ada sekitar 300 orang yang dapat menjadi pewaris aktif perabab. Tapi tidak semuanya pandai berdendang dan bercerita. Kesemua orang ini tersebar di setiap kecamatan di kabupaten Pesisir Selatan. Tabel berikut ini memperlihatkan sebaran pewaris kemahiran barabab di kabupaten Pesisir Selatan. Akan tetapi, hanya sedikit dari jumlah yang terpapar dalam daftar ini yang pandai menggesek rabab dan sekaligus mampu menuturkan kisah cerita dengan cara berdendang.

\begin{tabular}{lllll}
\hline No & Lokasi (kecamatan) & \multirow{2}{*}{$\begin{array}{l}\text { Jumlah } \\
\text { (orang) }\end{array}$} & & \multicolumn{2}{c}{ Jenis Kelamin } \\
\cline { 5 - 5 } & & 18 & 10 & 8 \\
\hline 1 & Tarusan & 20 & 13 & 7 \\
\hline 2 & Bayang & 40 & 36 & 4 \\
\hline 3 & IV Jurai & 22 & 20 & 2 \\
\hline 4 & Batang Kapeh & 29 & 22 & 7 \\
\hline 5 & Sutra & 68 & 40 & 28 \\
\hline 6 & Lengayang & 55 & 37 & 18 \\
\hline 7 & Ranah Pasisia & 55 & 36 & 19 \\
\hline 8 & Linggo Sari Baganti & 13 & 7 & 6 \\
\hline 9 & Pancung Soal & & & Perempuan \\
\hline
\end{tabular}


Pemda kabupaten Pesisir Selatan pernah melakukan upaya untuk memilih perabab terbaik di lingkup kabupaten tersebut. Perlombaan itu berhasil memilih lima orang perabab terbaik di kabupaten Pesisir Selatan. Yosdirman dan Iye yang menjadi dua orang informan penelitian ini berhasil masuk dalam kategori im aorang perabab terbaik tersebut. Terobosan baru telah dilakukan oleh Pemerintah Daerah Pesisir Selatan untuk mendukung upaya pelestarian seni tradisi barabab ini, yaitu tidak mengizinkan pertunjukan orgen tunggal dalam acara alek yang dilaksanakan pada malam hari. Kalapun akan menyuguhkan permainan orgen tunggal, itu hanya boleh dipertunjukan di siang hari saja. Kebijakan ini otomatis memberi ruang gerak yang lebih bebas dan lepas bagi tumbuh dan berkembangnya pertunjukan barabab di ranah Pesisir Selatan. Kebijakan seperti ini patut diberi apresiasi positif dan panats untuk dijadikan contoh bagi daerah kabupaten lainnya di provinsi Sumatera Barat.

Satu hal yang menarik dari pertunjukan rabab ini adalah bahwa ketika pertunjukan rabab dilaksanakan maka harus ada sirih jo langkuai (carano nan delapan sagi) dipersiapkan. Bila perlengkapan itu belum ada maka pertunjukan rabab belum dapat dilaksanakan. Akan tetapi aturan ini hanya berlaku pada pertunjukan rabab zaman dahulu, sementara pertunjukan barabab saat ini tidak lagi terlalu mengindahkan aturan demikian. Siriah jo langkuai (sejenis carano) berfungsi untuk "mengikatkan" tukang rabab di rumah itu. Tukang rabab bisa dikatakan pihak si alek, namun juga bisa dikatakan pihak si pangka. Dikatakan pihak si alek karena rombongan tukang rabab pasti datang dari jauh. Dikatakan pihak si pangka, karena mereka penghuni rumah semalam suntuk, telah tidur orang rumah yang mengundangnya bermain rabab, tukang rabab masih tidak tidur dan berjaga-jaga sambil bermain rabab.

\section{SIMPULAN}

Pemetaan seni pertunjukan Barabab dan pewaris kemahiran bermain rabab adalah suatu tindakan penting yang mesti dan harus dilakukan lebih serius kedepan. Pemetaan akan berguna untuk mengetahui kondisi terkini keberadaan pewaris seni pertunjukan Barabab. Kegiatan pemetaan juga diperlukan untuk menginventarisir keberadaan si pewaris aktif untuk diberdayakan sebagai pelatih atau guru pada kegiatan pelatihan yanag akan diselenggarakan sebagai suatu upaya pelestarian keterampilan bermain rabab, untuk generasi muda di tanah Pasisia. Pelatihan keterampilan Barabab kepada generasi muda direncanakan akan direalisasikan pada tahun kedua penelitian ini. Pembicaraan ke arah itu sudah dibahas dengan pemerintah daerah setempat. Pihak Pemda Pesisir Selatan memberikan respon cukup positif dan berencana akan membuat anggaran untuk pembiayaan kegiatan tersebut. Sebuah kawasan yang berdekatan dengan lokasi wisata alam yang memiliki sebuah air terjun, direncanakan akan dijadikan lokasi untuk tempat pelatihan keterampilan bermain rabab untuk generasi muda di tanah pasisia (pesisir). Memilih lokasi di tempat itu, cukup potensial, mengingat terdapatnya sebuah kawasan wisata alam dekat lokasi tersebut

\section{DAFTAR RUJUKAN}

Amir, Adriyetti dkk.1998. Pemetaan Sastra Lisan Minangkabau. Jakarta: ATL.

Dananjaya, James. 1991 (cet.ke-3).Folklor Indonesia: Ilmu Gosip, Dongeng, dan lain-lain. Jakarta: Graffiti.

Finnegan, Ruth. 1992. Oral Tradition and Verbal Arts: A Guide to Research Practices. London \& New York: Rotledge. 
Hasanuddin. 2010. "Wacana Manajemen Konflik dalam Ulu Ambekdi Padang Pariaman" Jurnal SALINGKA, Majalah Ilmiah Bahasa dan Sastra. Padang: Balai Bahasa (vol.7, No.2, Hal 137-151).

Hutomo, Suripan Sadi. 1989. Penelitian Sastra Lisan: Teori dan Praktek. Surabaya.

Junus, Umar. 1984. Kaba dan Sistem Sosial Minangkabau: Suatu Problema Sosiologi Sastra. Jakarta: Balai Pustaka.

Kaplan, David and Albert Manners. 1999. Teori Budaya (terj.). Yogyakarta: Pustaka Pelajar.

Kayam, Umar. 1981. Seni, Tradisi, Masyarakat. Jakarta: Sinar Harapan.

Koentjaraninggrat. 1986. (cet. ke-6). Pengantar Ilmu Antropologi. Jakarta: Aksara Baru.

Lord, Albert B. 1981. The Singer Of Tales. London: Harvard University Press.

Moleong, Lexy J. 2000. Metodologi Penelitian Kualitatif. Bandung: Remaja Rosdakarya.
Navis, A.A. 1986. Alam Terkembang Jadi Guru: Adat dan Kebudayaan Minangkabau. Jakarta: Grafffiti Pers.

Phillips, Nigel. 1981. Sijobang: Sung Narative Poetry of West Sumatera. Cambridge: Cambridge University.

Sedyawati, Edi. 1981. Pertumbuhan Seni Pertunjukan. Jakarta: Sinar Harapan.

Strauss, Claude-Levi. 1963. Structural Anthropology. New York: Basic Books.

---------1978. Myth and Meaning. London: Routledge and Paul.

Sweeney, Amin. 1985. Full Hearing: Orality and Literacy in the Malay World. Barkeley: University of California Press.

\section{UCAPAN TERIMA KASIH}

Atas dimuatnya artikel ini, penulis mengucapkan terima kasih kepada jajaran penyunting Jurnal Lokabasa. Semoga tulisan ini ada manfaatnya bagi kita semua. 